\title{
Pandemic, LaW, AND Indigenous Languages IN PAKISTAN
}

\author{
Muhammad Hassan Abbasi \\ Bahria University, Karachi Campus, Pakistan \\ Maya Khemlani David \\ Asia Europe Institute, University of Malaya, Malaysia
}

\begin{abstract}
Pakistan is a multilingual state with 74 languages (Siddiqui, 2019), with Urdu being its national language while English is its official language (Article 251 of the Constitution of the Islamic Republic of Pakistan). However, the linguistic diversity, as per the law, has not been given proper status in Pakistan (Rahman, 2002). In the wake of Covid-19 pandemic, the role of medical health professionals, local police officers, media persons and educationists to create an awareness about the precautionary measures to fight Covid-19 among the indigenous communities in different regions of Pakistan is important. However, there is no practice prescribed in the law, to disseminate awareness in the local languages. Moreover, as most of the lexical items regarding the pandemic have been borrowed, the shift to local languages is more than challenging. In urban areas, indigenous communities are aware of the precautions to be taken during this pandemic as they use the mainstream languages (Ali, 2017 \& Abbasi, 2019.) However, in the rural and northern areas of Pakistan this is not so prevalent. Some language activists and concerned members of the community in different parts of the state took this opportunity to educate the masses and started an awareness campaign about coronavirus pandemic in local languages (posters in local languages and short video messages on social media and YouTube). Yet, linguists and community members have not been able to work with many indigenous languages, which Rahman (2004) lists in his study, and these speech communities urgently need the required information in their respective heritage languages. Such small steps by community members and NGOs in providing necessary information in local languages suggest that proper education in the mother tongue can protect communities in times like this. The government has to protect endangered and indigenous languages by an effective law-making process that actively encourages the use of local languages and helps provide information in their respective languages in such situations as this pandemic.
\end{abstract}

Key words: Pandemic, mother tongue, law, language policy

\section{INTRODUCTION}

The official language policy of Pakistan states that English is the co-official language of Pakistan while Urdu is the national language and official language of Pakistan (Article 251 of the Islamic Republic of Pakistan) and one provincial language is recognized in each province as the provincial language (Torwali, 2014). In Pakistan the national language, Urdu has about $7.08 \%$ (Census-2017) mother tongue speakers while according to Abbasi (2019) it is used as a second language by most of the speakers in Pakistan. However, as per the practice English language is frequently used in administrative and educational domains (Zaidi \& Zaki, 2017). Because of power dimensions associated with the language; a distinctive variety of Pakistani English also exists that supports the elite and official bodies in the provinces and federal government (Rahman, 2006 \& Rahman, 2010). Despite the Government's enshrined principal in the 1973 constitution that 'arrangements will be made to make Urdu as the official language within fifteen years' and the Supreme Court's verdict that Urdu shall be the official language and steps shall be made to replace and adopt Urdu in the administration domains (Haider, 2015) yet, such a practice is still resisted because English is used in most of the domains of law like amendments, bills, resolutions, budget drafts presented in the Parliament and Senate; cabinet meetings, government orders and fact finding reports; court judgments in the family, session, high courts, and Supreme Court. Only in some cases is a translation of a judgment available in the local language, most often in Urdu and Sindhi. Despite the government's implementation plan presented in 


\section{Yinternational Research Journal}

p-ISSN 2202-2821 e-ISSN 1839-6518 (Australian ISSN Agency)

the Supreme Court, yet effective measures have not been taken to implement Article 251 in line with Article 5 of the constitution.

Similarly, the English language is used in the educational domain, where English is taught as a compulsory subject from Grade One to the Bachelor level. Also, the highest body of education in the state, Higher Education Commission (HEC) supports the use of English at all levels. Furthermore, Urdu is the second most popular medium of instruction in Pakistan, which is taught as a compulsory subject in government schools and colleges. In the provincial competitive exams, Urdu is also one of the compulsory subjects along with Sindhi, which is offered as an optional subject in the Sindh province (Rahman, 2002). Overall, English and Urdu are the most frequent languages in the education system along with provincial languages in the four provinces in a country which according to the Census (2017) and mentioned by Siddiqui (2019), has up to 74 languages. Sixty-six are indigenous languages while eight are non-indigenous. Furthermore, seven are institutional, seventeen are developing, thirty-nine are vigorous, nine are in danger and two are dying (Siddiqui, 2019). Endangered languages in Pakistan are fighting for their survival because of fewer number of speakers of languages which include Dameli, Gawar, Balti and Ushojo, along with Shina and Balti which are placed on the endangered languages list (Ahmed, 2017).

Census (2017) shows that Urdu is spoken by only $7.08 \%$ of the people, while Punjabi (38.78), Sindhi (14.57), Pashto (18.24), Balochi (3.02), Saraiki (12.19), Kashmiri (0.17), Hindko (2.24), Brohi (1.24) and other languages (2.47) are spoken as their first language by different speech communities (Daily Pahenjiakhbar, 2019). The other languages include the indigenous languages which have become a victim of law and language policy (Rahman, 2006). Due to the dominance of English and Urdu, other minority languages that are not recognized are dying (Torwali, 2014).

Despite all these barriers for indigenous languages, the lawmaking process in the provincial governments has achieved some success. For instance, in the Sindh province, mother tongue education is given in the Sindhi language because Sindhi speakers enjoy high ethnolinguistic vitality (David, Ali $\&$ Baloch, 2017). Therefore, the Sindhi language is used in the administrative domain as well (Abbasi, 2019). Hence, if a community has a positive attitude towards its language than efforts can be made to let the language flourish. Comparatively, the province of Khyber Pakhtoon kha (KPK)
Vol. 11 No. 012021 82801101202103

has a multilingual solution for its education system as Khowar, Hindko, Saraiki and Pashto are taught at school level (Zaidi \& Zaki, 2017). However, language activist Torwali (2014) states that the situation of minority languages in Pakistan is quite drastic 'as the speakers of these minority languages regard their languages to be of no use for them to be able to progress in life'. Notwithstanding this attitude some indigenous community members are taking some initiatives like the teaching of the Torwali language in some of the schools in KPK. Similarly, the Gujarati language in Sindh province, is also being taught by community members. Also, NGOs are taking steps to create the writing system in the local languages, for instance, Yidgha, a language spoken in Chitral has recently got its writing system through the support of Forum for Language Initiative (FLI, 2020). Yet, many languages like Kalasha, Domaaki, Odaki are dying or near to extinction (Ahmed in Latif, 2018).

Because the law does not facilitate education and research in many of the local languages with the appearance of Covid-19 it was important to disseminate vital information regarding how the people, especially indigenous communities could keep themselves safe. Educating and reaching the indigenous communities in the rural areas became important as the indigenous communities in the urban areas, were adopting the mainstream language/s like Urdu which as has been mentioned is spoken by only $7.08 \%$ population in Pakistan (Ali, 2015; Abbasi, 2019; \& Latif, 2018). Holistically, the indigenous communities think that they have to acquire Urdu and English or both and abandon their mother tongue in favor of Urdu or powerful provincial languages (Torwali, 2014).

The pandemic introduced a new reality. The first case of Corona virus was reported on February 26th, 2020 in Pakistan and preventive measures and strict lockdown were imposed by the government in March 2020 when the number of cases increased. When it came to disseminating information about the virus the major issue was lack of alternative vocabulary in the local languages. According to Ahmed (2020), the English language remained the only hope, because of its vast scope and experience in addressing many crisis and pandemic situations.

The government started to take measures to create health awareness among its public mainly in Urdu through newspapers and press conferences. However, the government was addressing one segment of the society -those who speak, read, and understand Urdu. Such messages could not be understood by those who did not read or write Urdu especially those in the rural and northern areas of Pakistan. It is not surprising that the Prime Minister stated that 'he is more

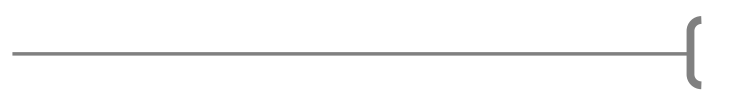




\section{Yinternational Research Journal}

p-ISSN 2202-2821 e-ISSN 1839-6518 (Australian ISSN Agency)

concerned about people living in low-income houses, who have no awareness about this Covid-19'. (Khan in Alvi, 2020).

However, the government did not take any measure to introduce a law in the Parliament or Provincial assemblies or seek the help of local linguists and indigenous communities to disseminate safe-guarding information about corona virus to the indigenous communities. In fact, the highest forum of lawmaking beside the Parliament, the Supreme Court of Pakistan took a Suo-moto notice of government's measure to combat coronavirus pandemic situation in Pakistan. Ironically, all the court proceedings and the final judgment were in English, despite the court's order to use Urdu as the official language. (Haider, 2015).

\section{Objective}

This paper analyses the absence of effective law-making policies in response to Covid-19 and its impact on the indigenous communities, health sector, education sector, and policing. It discusses the steps taken by the community members in the different areas of Pakistan.to inform specific speech communities who were not able to read or understand the information provided in government leaflets regarding the pandemic.

\section{Methodology}

Secondary literature, interviews and observation were used to review available literature regarding the law-making policies and language choices in Pakistan. During Covid-19, the role of health professionals was highly significant, and a face-to face one hour interview with a Doctor working in Karachi, Sindh, who happens to be a member of an indigenous community was held to analyze the impact of official language policy on the health sector during Covid-19.

As health professionals frequently use technical vocabulary, such lexical items were reported in local newspapers Daily Jang and Kawish (headlines on the front pages of the newspapers. Furthermore, an online session on 'Policing in Covid-19' and Suo-moto judgment document by the Supreme Court of Pakistan has been analyzed to highlight the importance of language choices. In addition, the videos made and uploaded on the social media by indigenous community members using local languages to create awareness with regard to Covid-19 have been analyzed.

\section{Findings}

Covid-19 Pandemic made the role of local community members, local police officers, health professionals and media persons highly important as the government was initially
Vol. 11 No. 012021

82801101202103

unable to reach all the citizens in their respective mother tongues to inform them of steps to safeguard themselves. At first, the government issued necessary standard operating procedures (SOPs) to create awareness among the different indigenous communities. This information was given in Urdu and all the documentation was done in English. Some provincial governments in collaboration with WHO (World Health Organization), NDMA (National Disaster Management Authority) and Ministry of National Health Services, Regulations and Coordination (NHSRC) created awareness through advertisements on television and newspapers, especially local language newspapers, among people residing in the rural areas and the northern areas of Pakistan. However, no law that facilitates and promotes indigenous languages to create awareness among the masses against Covid-19 was passed in the provincial and federal legislative assemblies.

\section{A. Health and Law in Pandemic}

In this pandemic, the front runners in the war against Covid-19 were the health professionals. These medical professionals followed the orders of the Government and advised, dealt with, and treated community members in different parts of Pakistan in a language unknown to several indigenous communities. During the interview with one of the researchers, the health professional informed that 'the scientific vocabulary and explanation in the local language was missing and we have to use a list of foreign words (borrowing) from the official language because an equivalent in the local language was not found, so we have to rely on the English terminology (DHA001).

Some federal and provincial governments did introduce awareness campaigns to deal with the pandemic and introduced basic precautionary courses in collaboration with foreign institutes to deal with Covid-19. However, "the different courses offered were taught in English, while in hospitals and emergency centers, a larger segment of the society do not understand English' (DHA001). As a result, medical health professionals, used the same explanation as taught in the courses while communicating with the public. They used a list of borrowed words because the alternative words in local languages were not available. Table 1 below shows the list of borrowed words used by the health professionals in explanations to Covid-19 patients. These words were also used by journalists in the local newspapers, social media, and national television.

\section{B. Policing and Law in Pandemic}

In a seminar on Policing in Covid-19, Abbasi (2020), IGP $\mathrm{KPK}$; delivered an online lecture to academia and university

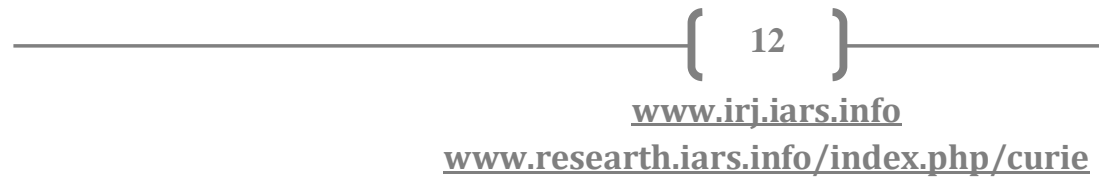




\section{Yinternational Research Jourmal}

p-ISSN 2202-2821 e-ISSN 1839-6518 (Australian ISSN Agency)

students. (Bureau of Students Tutorial Guidance/Counseling Services STAGS; University of Sindh, 2020) In the lecture, the speaker frequently used English and Urdu. In fact, the local policing terminology and the role of law enforcement agencies to "educate, engage and enforce" was provided in English. Abbasi (2020) while reflecting on the pandemic frequently used more English words than Urdu words. These words included, "operate, monitor, protect, first respondents, surveillance, drone cameras, video conferencing, crime, domestic crime, border crime, imprisonment, punishment, cybercrime ethical role, misconceptions and propaganda". At times, an Urdu alternative could have been used like taleem, dekhna, jurm, hifazat krna, saza and qaid though in some cases there were no alternatives in Urdu. The same terms generally in English were then frequently used in the newspapers.

Table 1

Frequent Words used to Explain the Covid-19 Virus (Source Daily Kawish/Jang Newspaper)

\begin{tabular}{|l|l|l|l|}
\hline Case & Hand sanitizer & Pandemic & Virus \\
\hline Cough & Isolation & Plastic bags & Ward \\
\hline Corona & Influenza & Report & Yoga \\
\hline Covid-19 & Immunity & Screening & \\
\hline Disinfect & Kits & Sample & \\
\hline Disease & Laboratory & Self-isolation & \\
\hline Depression & Mask & Testing & \\
\hline Emergency & N-95 mask & Treatment & \\
\hline Face mask & Mobile testing & Test & \\
\hline Gloves & Oxygen mask & Ventilator & \\
\hline Hand gloves & $\begin{array}{l}\text { Oxygen } \\
\text { cylinders }\end{array}$ & Vaccine & \\
\hline
\end{tabular}

\section{Legal Practice and Law}

The highest judicial forum in Pakistan, Supreme Court in its 2015 judgment, regarding promotion and implementation of the Urdu language, emphasized the fact that in the 'governance of federal and provincial government, there is hardly any obligation for rulers to use colonial language which cannot be comprehended by a larger segment of the public' (Haider, 2015). However, the Supreme Court in its own SuoMoto notice on corona-virus documented the fact that the 'Coronavirus (Covid-19) has spread and infected considerable
Vol. 11 No. 012021 82801101202103

portion of the society' and discussed the situation about availability of 'ventilators' and 'Personal Protective Equipment' (See Supreme Court Suo-moto case judgment regarding government's measure on Coronavirus pandemic, 2020) and passed the judgment using English. Therefore, despite the court's order that Urdu should be the official language, English appears to have been the preferred language in the legal fraternity

\section{Indigenous Languages and Law in Pandemic}

Despite the use of terminology and statements regarding Covid-19 which were made in English some positive steps have been taken by local community members. Community members along with NGOs (Viral languages \& Forum for language initiative) in Gilgit, Baltistan and northern areas started a campaign to educate the people using local languages and social media and YouTube. Indigenous language speakers belonging to Kalasha (spoken in the Kalash valley of Chitral) Kalkoti, Khowar, Kohstani, Dameli, Shina, Burushaski, Yidgha (a highly endangered language, spoken in the Lotkuh valley of Chitral), Torwali, Pulala, and Gwaki became part of this initiative and made vital information about the virus and protection from the virus available in local languages. A similar practice has been followed worldwide, as Drude (2020) notes that Doctors of the World organization in the UK has translated information into 49 languages including Pashto, Punjabi, Sindhi and Urdu etc. So, in Pakistan, Viral languages and Forum for Language Initiative (FLI) has taken this step to make videos in the local languages and upload it on the social media and YouTube. In these videos, the speakers shared their recommendations, precautionary measures, experience and useful ways to avoid getting infected by Coronavirus in local languages. As coronavirus has direct and indirect impact on indigenous communities indigenous language speakers and Forum for Language Initiative (FLI) in collaboration with the Government of Pakistan have developed banners in eleven indigenous languages of northern Pakistan, which are being displayed in the local communities to create awareness among people (See Figure 1 in local languages and Figure 2 in English).

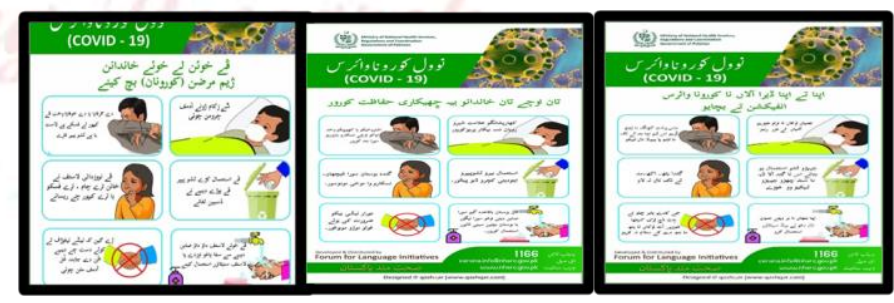

Figure 1: Awareness Banners for the Protection from Covid-19 (Source: Forum for Language Initiative) 


\section{Yimternational Research Journal}

p-ISSN 2202-2821 e-ISSN 1839-6518 (Australian ISSN Agency)

Also, individual community members in Sindh, Punjab and KPK shared similar messages in Sindhi, Punjabi, Dhatki and Pashto. However, at least four speakers from the Gujarati community in Karachi when asked to record a message for awareness against the pandemic; reported that they cannot record a message in Gujarati because they do not know the technical vocabulary i.e. lexical words to record a message for awareness against Covid-19 pandemic. It was clear when analyzing the video recording shared by the NGOs and community members that almost all of the speakers of the indigenous communities frequently used the word "virus" although an Urdu equivalent "waba" exists.

Overall, the findings reflect that despite awareness on the social media initiated by community members and NGOs, a large segment of indigenous language speakers in different parts of Pakistan are neglected (see Rahman, 2004 and Siddiqui, 2019). The challenges faced by the indigenous community members in the education, health, media, and policing domains are fundamental and requires the attention of the government and law-making institutions. Due to the absence of a language policy regarding local languages language shift and loss has occurred. However, as language policy and implementation cannot be changed overnight, it is fortunate that community members like Zubair Torwali and NGOs and bodies like SIL International, Viral languages and Forum for Language Initiative are trying to revive languages through music, primary education in the local languages, and are at this critical juncture providing vital information in a number of ways and forms so that such knowledge can save lives during this pandemic.

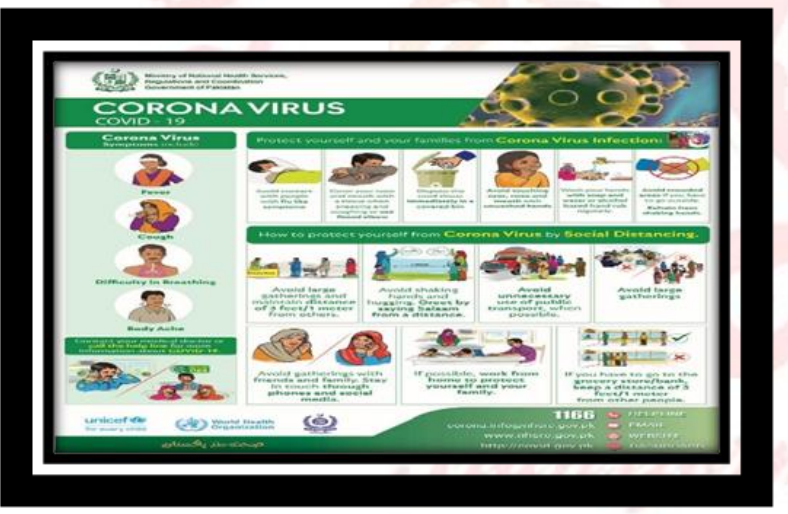

Figure 2: Awareness Banners for the Protection from Covid-19 (Source: Ministry of National Health Service, Regulation and Coordination).

\section{Conclusion:}

These examples from the law, education, medical and administrative domains show that there is little or no space for
Vol. 11 No. 012021

82801101202103

indigenous languages. Pakistan is considering a decisive change in the education system and efforts are being made to make Urdu the official language, along with the teaching of mother tongue in the provinces. The first step will be to name all the local languages in a unified government document. The next step is to introduce mother tongue education at the primary level along with Urdu and English as compulsory subjects. Laws take time to change. In the interim during this pandemic indigenous community members along with NGOs have started to act as intermediaries providing vital information in local languages for indigenous community members who do not know Urdu or English.

\section{REFERENCES}

[1]. Abbasi, Sanullah. (2020). Policing in Covid-19 Pandemic Situation. University of Sindh, Jamshoro.

[2]. Abbasi, M. H. (2019). Language Shift and Maintenance: A Case Study of Sindhi-Speaking Urban Youth. (MS Thesis, Department of Humanities, NEDUET, Karachi).

[3]. Ahmed, Khaleed. (2020). The English Medium Problem. Newsweek.

[4]. Ahmad, Naseer. (Feb 4, 2017). Mother and the mother tongue. Dawn.com

[5]. Ali, S. S. (2017). Language Shift and Ethnolinguistic Vitality: a sociolinguistic study of Indigenous minority language speakers in Karachi. (PhD thesis, Department of English, UoK)

[6]. Alvi, Mumtaz. (2020). Decision to lockdown forced by Elite- PM Imran Khan. Thenewscom.pk.

Retrieved from

https://www.thenews.com.pk/print/652173-decisionto-lockdown-forced-by-elite-imran

[7]. Census. (2017). Census report of Pakistan. Islamabad: Population Census Organization Statistics Division. Government of Pakistan.

[8]. Constitution of Pakistan. (1973). The National Assembly, Government of Pakistan. Retrieved from http://www.na.gov.pk/uploads/documents/133352368 1_951.pdf.

[9]. Daily Pahenjiakhbar (8th April, 2019). Retrieved from www.pahenjiakhbar.com.

[10]. Daily Jang Newspaper. (March-June, 2020) Headlines.

[11]. Daily Kawish Newspaper (March-June, 2020), Headlines. ABC Certified.

[12]. David, M. K., Ali. M., \& Baloch, G. M. (2017). Language Shift or maintenance: The Case of Sindhi

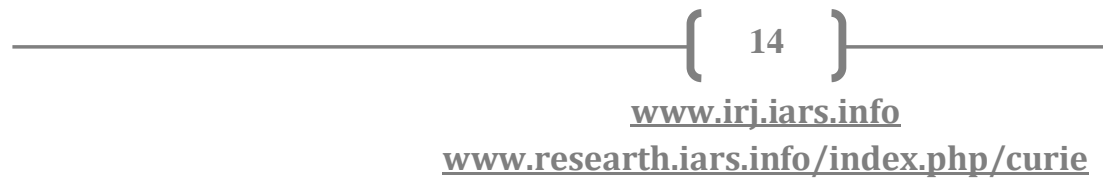


Language in Pakistan. Language Problem \&

Planning, 41(1), 26-45

[13]. Drude, Sebastian. (2020). Covid-19 and minority and lessor known languages. Retrieved from http://www.ogmios.org/blog/covid-19-and-minorityand-lesser-known-languages/

[14]. Forum for Linguistic Initiatives (2020). Retrieved from https://fli-

online.org/site/?fbclid=IwAR0PmOhhHzq5PDei0AQ 1MmE9rfO7Mo9BLzfU3nJliaKvKQS1GQCdmB6x1 n4

[15]. Haider, Irfan. (Sept8, 2015). Supreme Court orders Govt. to adopt Urdu as official language. Dawn.com. Retrieved from https://www.dawn.com/news/1205686

[16]. Latif, Aamir (2018). Pakistan several regional languages face extinction. Anadolu Agency. Retried from https://www.aa.com.tr/en/asia-pacific/pakistanseveral-regional-languages-face-extinction/1071368

[17]. Policing in Covid-19. (2020). Bureau of STAGS, University of Karachi. Retrieved from https://www.facebook.com/bostags

[18]. Rahman, T. (2002). Language, Ideology and Power: Language Learning among the Muslims of Pakistan and North India. Oxford University Press: Karachi.

[19]. Rahman, T. (2004). Denizens of Alien Worlds: A Study of Education, Inequality and Polarization in Pakistan. Oxford and Karachi: Oxford University Press.

[20]. Rahman, T. (2006). Language policy, language vitality and multilingualism in Pakistan. In A.

Saxena\& L. Borin (Eds.), Trends in Linguistic: Lesser Known Languages of South Asia (pp. 73106). Berlin: Mouton de Grutyer.

[21]. Rahman, T. (2010). Pakistani English.2nd edition. Islamabad: Quaid - i - Azam University.

[22]. Siddiqui, Ali Shadid (2019). When a language dies. The News. Retrieved from https://www.thenews.com.pk/print/423539-when-alanguage-dies.

[23]. SIL International Retrieved from https://www.sil.org/

[24]. Supreme Court of Pakistan (2020), Suo Moto Case Bo 1 of 2020.

[25]. Torwali, Zubair (Feb, 20. 2014). Our Language Tragedy: A report from Pakistan. Living tongues. Retrieved from https://livingtongues.org/ourlanguage-tragedy-a-report-from-pakistan/

[26]. Zaidi, S.B \& Zaki, S. (2017). English Language in Pakistan: Expansion and Resulting Implications.
Journal of Education and Social Sciences. 5(1). 5267.

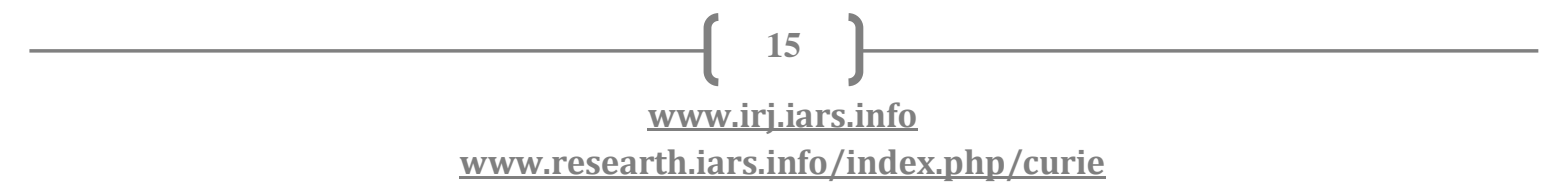




\section{Manuscript Processing Footprints}

\section{A. Journal Volume/Issue Details}

This manuscript it published in Vol. 11 No. 012021 issue of IARS' International Research Journal (I'IRJ) This is a Peer Reviewed (Refereed) International Journal archived with National Library of Australia.

The mentioned Volume/Issue is a special issue of the journal dedicated to Covid19 Pandemic Conditions across globe.

\section{B. Citation}

Abbasi, Muhammad Hassan and David, Maya Khemlani (2021) "PANDEMIC, LAW, AND INDIGENOUS LANGUAGES IN PAKISTAN", IARS' International Research Journal. Vic. Australia, 11(1). Available at: https://researth.iars.info/index.php/curie

\section{Author Declaration}

- The submission has not been previously published, nor is it before another journal for consideration (or an explanation has been provided in Comments to the Ed itor).

- The submission file is in OpenOffice, Microsoft Word, or RTF document file format.

- Where available, URLs for the references have been provided.

- The text is single-spaced; uses a 12-point font; employs italics, rather than underlining (except with URL addresses); and all illustrations, figures, and tables are placed within the text at the appropriate points, rather than at the end.

- The text adheres to the stylistic and bibliographic requirements outlined in the Author Guidelines.

- All Terms and Conditions about submission and publishing with IARS' International Research Journal on its official site and other sources have been gone through, understood, and accepted.

- With submission, this is declared that the submitter has all rights of the content, and to submit it. Also the submitter affirms that the rights of the submitted content are hereby transferred to IARS' international Research Journal and its parent company/publisher, without objections or conditions.

\section{Last Plagiarism Report}

Settings : similarity of 09 words in a row considered plagiarized.

Originality Assessment

\section{Overall Similarity: $2 \%$}

Date: Dec 17, 2020

Statistics: 59 words Plagiarized / 3597 Total words

Remarks: Low similarity detected, check your supervisor if changes are required. Sources

https://www.researchgatenet/profile/Muhammad_Abbasi22
INTERNET
$1 \%$

\section{E. Processing Track}

\begin{tabular}{|l|l|}
\hline Date of Submission: & 08 November 2020 \\
\hline Date of Referee/Review - 1: & 23 November 2020 \\
\hline Date of Referee/Review - 2: & 30 November 2020 \\
\hline Date of Additional Review: & NA \\
\hline Date of Acceptance: & 17 December 2020 \\
\hline Date of Publishing: & 08 February 2021 \\
\hline
\end{tabular}

